\title{
Antimicrobial Resistance in Enterococcus spp. Isolated from Environmental Samples in an Area of Intensive Poultry Production
}

\author{
Vesna Furtula $^{1}$, Charlene R. Jackson ${ }^{2, *}$, Erin Gwenn Farrell ${ }^{1}$, John B. Barrett ${ }^{2}$, \\ Lari M. Hiott ${ }^{2}$ and Patricia A. Chambers ${ }^{1}$
}

1 Environment Canada, Pacific Environment Science Centre, 2645 Dollarton Highway, North Vancouver, BC V7H 1B1, Canada; E-Mails: vesna.furtula@ec.gc.ca (V.F.); gwennfar@gmail.com (E.G.F.); Patricia.Chambers@ec.gc.ca (P.A.C.)

2 Bacterial Epidemiology and Antimicrobial Resistance Research Unit, USDA-ARS, Russell Research Center, 950 College Station Road, Athens, GA 30605, USA;

E-Mails: benny.barrett@ars.usda.gov (J.B.B.); lari.hiott@ars.usda.gov (L.M.H.)

* Author to whom correspondence should be addressed; E-Mail: charlene.jackson@ @ars.usda.gov; Tel.: +1-706-546-3604; Fax: +1-706-546-3616.

Received: 15 January 2013; in revised form: 20 February 2013 / Accepted: 4 March 2013 / Published: 12 March 2013

\begin{abstract}
Enterococcus spp. from two poultry farms and proximate surface and ground water sites in an area of intensive poultry production were tested for resistance to 16 clinical antibiotics. Resistance patterns were compared to assess trends and possible correlations for specific antimicrobials and levels of resistance. Enterococci were detected at all 12 surface water sites and three of 28 ground water sites. Resistance to lincomycin, tetracycline, penicillin and ciprofloxacin in poultry litter isolates was high $(80.3 \%, 65.3 \%$, $61.1 \%$ and $49.6 \%$, respectively). Resistance in the surface water to the same antibiotics was $87.1 \%, 24.1 \%, 7.6 \%$ and $12.9 \%$, respectively. Overall, $86 \%$ of litter isolates, $58 \%$ of surface water isolates and $100 \%$ of ground water isolates were resistant to more than one antibiotic. Fifty-four different resistance patterns were recognised in isolates obtained from litter and environmental samples and several E. faecium and E. faecalis isolates from litter and environment samples shared the same resistance pattern. Multiple antibiotic resistant (MAR) indices calculated to assess health risks due to the presence of resistant enterococci suggested an increased presence of antibiotics in surface water, likely from poultry sources as no other wastewater contributions in the area were documented.
\end{abstract}


Keywords: Enterococci; antimicrobial; resistance; poultry litter; ground water; surface water; contamination

\section{Introduction}

Microbial contamination of water bodies due to municipal wastewater plants and animal operations is recognized as a growing issue. Wastewater and animal waste are reservoirs of antibiotic-resistance genes and multiple antibiotic-resistant (MAR, defined as resistance to at least two antimicrobials) pathogenic bacteria that pose a threat to human health [1-3]. Enterococci are a major colonizer of animal and human intestinal tracts and certain enterococcal strains may be source specific, making them suitable as a bacterial source tracking indicator [4,5]. Enterococci have been recognized as a leading cause of nosocomial infections, the majority of which are caused by Enterococcus faecalis and Enterococcusfaecium [6,7], although other enterococcal species may also cause infections [8]. Enterococcal antimicrobial resistance has been observed in environmental isolates in many different studies [9-11]. Acquired resistance to a number of antibiotics, including vancomycin and aminoglycosides, presents a problem in treatment of enterococcal infections as well as posing a threat of resistance spreading into the environment via the transfer of antimicrobial resistance genes and some virulence factors from enterococci to pathogenic bacteria [12].

The Fraser Valley in British Columbia is the poultry capital of Canada, with poultry-related solid waste production exceeding 320,000 tonnes per year. Several studies have documented poultry litter as a potential reservoir for MAR bacteria [13-15]. Resistant bacteria and associated genes can persist over a long period of time in poultry litter and be subsequently released into the environment upon subsequent application of the litter as a fertilizer $[13,16,17]$. When poultry litter is used as a fertilizer or soil conditioner, multi-resistant bacteria can find their way into surface and ground waters via runoff or seepage, especially in areas where precipitation is plentiful $[13,18]$. Monitoring of antimicrobial resistance of fecal bacteria in surface water (mainly E. coli and Enterococcus) has been conducted throughout much of the World [11,19]. Although a few of these studies have investigated resistance of enterococcal species and their dissemination into surface water [20,21], to our knowledge environmental studies on occurrence of MAR bacteria in surface and ground water near poultry farms or farms using poultry litter as fertilizer have not been conducted.

In this study, we investigated enterococci from different environments (poultry litter, surface and ground water) in areas of intensive poultry production to evaluate trends and correlations in specificity and levels of antibiotic resistance. MAR indices, the incidence of multiple-antibiotic resistant isolates among isolates from a sample, were calculated and applied to enterococci isolates to differentiate between low and high risk resistance bacterial contaminated sites. 


\section{Experimental Section}

\subsection{Surface and Ground Water Sampling}

Surface and ground water samples were collected from 12 and 28 sites, respectively, in the Abbotsford area of British Columbia, Canada, near poultry farms and berry farms that used poultry litter as fertilizer, as well as a reference site in a residential area in Port Moody, British Columbia [22]. Ground water sites were sampled in April, August, and December of 2009. Surface water samples were collected in December 2009 by submerging sterile $500 \mathrm{~mL}$ bottles approximately $50 \mathrm{~cm}$ below the water surface. For ground water samples, three full well volumes were purged from the piezometre using a submersible pump located close to the well screen. A minimum of three line volumes were purged from the sample tubing (low density polyethylene waterra tubing, dedicated for each well to prevent cross contamination) prior to sample collection using a Hydrolift pump. Both surface and ground water samples were transferred to $250 \mathrm{~mL}$ sterile polypropylene bottles containing sodium thiosulfate $(10 \mathrm{mg} / 250 \mathrm{~mL}$ bottle) as provided by the laboratory. All water samples were placed on ice packs in coolers $\left(\sim 4{ }^{\circ} \mathrm{C}\right)$ and shipped to the laboratory where they were kept in a cold-room $\left(\leq 4{ }^{\circ} \mathrm{C}\right)$. Samples were analyzed within $24 \mathrm{~h}$ of collection.

Litter samples were collected from two different poultry farms, one broiler farm (where birds are reared for rapid growth and slaughtered for meat) and one layer farm (where hens are reared for egg production). Nine locations in four different barns of each farm type (broiler and layer) were sampled. Broiler farms were sampled on day 3 and day 35 of production (after application of new litter and introduction of birds). All samples were collected using gloves and sterile scoops and placed into sterile Falcon tubes. The samples were kept on ice until analysis, which was performed within $24 \mathrm{~h}$ of collection, except for samples from one layer barn where samples were frozen after collection and analyzed at a later date.

\subsection{Isolation and Identification of Enterococci}

Isolation of enterococci from water samples was performed using a membrane filtration technique. Samples $(100 \mathrm{~mL})$ were filtered through a $0.45 \mu \mathrm{m}$ membrane sterile filter and incubated on $\mathrm{mE}$ agar for $48 \mathrm{~h}$ at $41{ }^{\circ} \mathrm{C}$ followed by incubation on Esculin Iron Agar (EIA) for $20 \mathrm{~min}$ at $41{ }^{\circ} \mathrm{C}$ as previously described [23]. Colonies that appeared pink to red with dark precipitation on EIA were verified using Biolog Microbial ID system in combination with the Biolog Gram Positive Aerobic Bacteria Database (Release 6.01, Biolog, Hayward, CA, USA). For poultry litter samples, 5-6 g of litter was weighed and dispensed into $10 \mathrm{~mL}$ of $0.85 \%$ sterile saline in a sterile $50 \mathrm{~mL}$ Falcon tube. The tube was vortexed on high for one minute and serial dilutions were plated on KF streptococcal agar (Difco, Detroit, MI, USA). Red or pink colonies on the KF agar were verified using Biolog Microbial ID system in combination with the Biolog Gram Positive Aerobic Bacteria Database (Release 6.01, Biolog, Hayward, CA, USA). Isolated colonies of confirmed Enterococcus were inoculated into $5 \mathrm{~mL}$ of tryptic soy broth containing $6.5 \% \mathrm{NaCl}$ and incubated for $5-12 \mathrm{~h}$ at $35{ }^{\circ} \mathrm{C}$; one $\mathrm{mL}$ of this culture was then combined with $325 \mu \mathrm{L}$ of $80 \%$ glycerol and stored at $-40{ }^{\circ} \mathrm{C}$ until further analysis. Isolates identified as the genus Enterococcus using Biolog were confirmed as Enterococcus and identified to species level using multiplex PCR [24]. 


\subsection{Antimicrobial Resistance Testing}

Minimum inhibitory concentrations (MIC, $\mu \mathrm{g} \cdot \mathrm{mL}^{-1}$ ) for enterococci were determined by broth microdilution using the Sensititre ${ }^{\mathrm{TM}}$ semi-automated antimicrobial susceptibility system (Trek Diagnostic Systems, Inc., Cleveland, OH, USA) and the Sensititre ${ }^{\mathrm{TM}}$ Gram-Positive Custom Plate CMV2AGPF. CLSI (Clinical and Laboratory Standards Institute, Wayne, PA, USA) antimicrobial resistance breakpoints were used whenever possible; however, no CLSI interpretive criteria have been defined for kanamycin and tylosin and only susceptible breakpoints (not resistant) have been established for daptomycin $\left(\leq 4 \mu \mathrm{g} \cdot \mathrm{mL}^{-1}\right)$ and tigecycline $\left(\leq 0.25 \mu \mathrm{g} \cdot \mathrm{mL}^{-1}\right)$. Breakpoints for daptomycin, kanamycin, lincomycin, tigecycline, and tylosin were those defined by the National Antimicrobial Resistance Monitoring System (NARMS) [25]. The Gram-Positive Custom Plate CMV2AGPF panel of 16 antimicrobials and breakpoints for classification as resistant used by the NARMS program and important in human medicine were as follows: chloramphenicol $\left(\geq 32 \mu \mathrm{g} \cdot \mathrm{mL}^{-1}\right)$, ciprofloxacin $\left(\geq 4 \mu \mathrm{g} \cdot \mathrm{mL}^{-1}\right)$, daptomycin $\left(\geq 8 \mu \mathrm{g} \cdot \mathrm{mL}^{-1}\right)$, erythromycin $\left(\geq 8 \mu \mathrm{g} \cdot \mathrm{mL}^{-1}\right)$, gentamicin $\left(\geq 500 \mu \mathrm{g} \cdot \mathrm{mL}^{-1}\right)$, kanamycin $\left(\geq 500 \mu \mathrm{g} \cdot \mathrm{mL}^{-1}\right)$, lincomycin $\left(\geq 4 \mu \mathrm{g} \cdot \mathrm{mL}^{-1}\right)$, linezolid $\left(\geq 8 \mu \mathrm{g} \cdot \mathrm{mL}^{-1}\right)$, nitrofurantoin $\left(\geq 128 \mu \mathrm{g} \cdot \mathrm{mL}^{-1}\right)$, penicillin $\left(\geq 16 \mu \mathrm{g} \cdot \mathrm{mL}^{-1}\right)$, streptomycin $\left(\geq 1,000 \mu \mathrm{g} \cdot \mathrm{mL}^{-1}\right)$, Synercid ${ }^{\circledR}$ (quinupristin/dalfopristin) $\left(\geq 4 \mu \mathrm{g} \cdot \mathrm{mL}^{-1}\right)$, tetracycline $\left(\geq 16 \mu \mathrm{g} \cdot \mathrm{mL}^{-1}\right)$, tigecycline $\left(\geq 0.5 \mu \mathrm{g} \cdot \mathrm{mL}^{-1}\right)$, tylosin $\left(\geq 32 \mu \mathrm{g} \cdot \mathrm{mL}^{-1}\right)$, and vancomycin $\left(\geq 32 \mu \mathrm{g} \cdot \mathrm{mL}^{-1}\right)$. Enterococcus faecalis ATCC 29212 , E. faecalis ATCC 51299, Staphylococcus aureus ATCC 29213 and Escherichia coli ATCC 25922 were used as quality controls for determination of MIC.

\subsection{Data Analysis}

Resistance results were interpreted according to CLSI guidelines when defined [26,27]. Categories of antimicrobial resistance were susceptible, intermediate and resistant according to NARMS classification [25].

\subsection{MAR Index}

The MAR index was calculated to compare the resistance level of isolates across different areas and sample types using the following equation [28]:

$$
\operatorname{MAR}_{\text {index }}=\mathrm{a} / \mathrm{b} \times \mathrm{c}
$$

where "a" represents number of antibiotics to which isolates were resistant, "b" represents the number of antibiotics to which isolates were exposed, and "c" represents the number of isolates per sample.

\section{Results and Discussion}

\subsection{Bacterial Recovery}

Analysis of data from 12 surface water and 28 ground water sites in an area of intensive poultry farming showed that all surface water samples $(\mathrm{n}=85)$ tested positive for Enterococcus, with counts ranging from 1 to $2,100 \mathrm{cfu} / 100 \mathrm{~mL}$ (Table 1). 
Table 1. Distribution of Enterococcus from surface water, ground water and poultry litter.

\begin{tabular}{|c|c|c|c|c|c|c|c|c|c|c|}
\hline \multirow[b]{2}{*}{ Sample } & & \multicolumn{9}{|c|}{ No. $(\%)$ of samples containing: } \\
\hline & $\mathbf{n}$ & E. faecalis & E. faecium & E. casseliflavus & E. durans & E. gallinarum & E. hirae & E. mundtii & E. raffinosus & $\begin{array}{c}\text { All other } \\
\text { species }\end{array}$ \\
\hline \multicolumn{11}{|l|}{ Surface Water } \\
\hline S1 & 8 & 0 & $4(50)$ & 0 & $1(12.5)$ & 0 & 0 & $3(37.5)$ & 0 & 0 \\
\hline S2 & 5 & 0 & $3(60)$ & $2(40)$ & 0 & 0 & 0 & 0 & 0 & 0 \\
\hline S3 & 8 & 0 & $4(50)$ & $1(12.5)$ & 0 & 0 & $1(12.5)$ & 0 & $1(12.5)$ & $1(12.5)$ \\
\hline S4 & 10 & $5(50)$ & $1(10)$ & 0 & 0 & 0 & $1(10)$ & $3(30)$ & 0 & 0 \\
\hline S5 & 2 & 0 & $1(50)$ & 0 & $1(50)$ & 0 & 0 & 0 & 0 & 0 \\
\hline S6 & 10 & $4(40)$ & $4(40)$ & 0 & $1(10)$ & $1(10)$ & 0 & 0 & 0 & 0 \\
\hline S7 & 7 & $1(14.3)$ & $2(28.6)$ & $1(14.3)$ & $2(28.6)$ & $1(14.3)$ & 0 & 0 & 0 & 0 \\
\hline S8 & 10 & $10(100)$ & 0 & 0 & 0 & 0 & 0 & 0 & 0 & 0 \\
\hline S9 & 9 & 0 & $1(11.1)$ & 0 & 0 & 0 & 0 & 0 & 0 & $8(88.9)$ \\
\hline S10 & 2 & $1(50)$ & $1(50)$ & 0 & 0 & 0 & 0 & 0 & 0 & 0 \\
\hline S11 & 7 & $2(28.6)$ & $1(14.3)$ & $2(28.6)$ & 0 & 0 & $1(14.3)$ & $1(14.3)$ & 0 & 0 \\
\hline $\mathrm{S} 12$ & 7 & 0 & 0 & $2(28.6)$ & $1(14.3)$ & 0 & 0 & $4(57.1)$ & 0 & 0 \\
\hline Total & 85 & $23(27.1)$ & $22(25.9)$ & $8(9.4)$ & $6(7.1)$ & $2(2.4)$ & $3(3.5)$ & $11(12.9)$ & $1(1.2)$ & 9 \\
\hline \multicolumn{11}{|l|}{ Ground Water } \\
\hline BC-008 & 5 & 0 & $1(20)$ & 0 & $3(60)$ & 0 & $1(20)$ & 0 & 0 & 0 \\
\hline $91-11$ & 1 & $1(100)$ & 0 & 0 & 0 & 0 & 0 & 0 & 0 & 0 \\
\hline US-02 & 1 & $1(100)$ & 0 & 0 & 0 & 0 & 0 & 0 & 0 & 0 \\
\hline Total & 7 & $2(28.6)$ & $1(14.3)$ & 0 & $3(42.9)$ & 0 & $1(14.3)$ & 0 & 0 & 0 \\
\hline Total Environment & 92 & $25(27.2)$ & $23(25)$ & $8(8.7)$ & $9(9.8)$ & $2(2.2)$ & $4(4.3)$ & $11(12)$ & $1(1.1)$ & $9(9.8)$ \\
\hline \multicolumn{11}{|l|}{ Poultry Litter } \\
\hline Layers & 29 & 0 & $29(100)$ & 0 & 0 & 0 & 0 & 0 & 0 & 0 \\
\hline Broilers (day 3) & 105 & $30(28.6)$ & $16(15.2)$ & $1(0.95)$ & $1(0.95)$ & $28(26.7)$ & $27(25.7)$ & 0 & 0 & $2(1.9)$ \\
\hline Broilers (day 35) & 29 & $6(20.7)$ & $21(72.4)$ & 0 & $1(3.4)$ & 0 & $1(3.4)$ & 0 & 0 & 0 \\
\hline Total & 163 & $36(22.1)$ & $66(40.5)$ & $1(0.6)$ & $2(1.2)$ & $28(17.2)$ & $28(17.2)$ & 0 & 0 & $2(1.2)$ \\
\hline
\end{tabular}


By comparison, the reference site sampled on all three occasions did not test positive for Enterococcus. Enterococci were detected in three of the 28 ground water sites ( $\mathrm{n}=92$ water samples; Table 1) with bacterial counts ranging from 1 to $5 \mathrm{cfu} / 100 \mathrm{~mL}$. Although there are no regulations for enterococci in surface or ground water in Canada, several locations did not meet the mandatory European Union standards of $400 \mathrm{cfu} / 100 \mathrm{~mL}$ for inland waters and $200 \mathrm{cfu} / 100 \mathrm{~mL}$ for coastal or transitionary waters [29].

Enterococci have long been recognized as an indicator of fecal contamination; however, there are few studies about their resistance and distribution in surface water [20,21] and to our knowledge, no such studies for ground water. In our study, seven enterococci were isolated from ground water samples from three sites, 85 were isolated from 12 surface water sites, and 163 were isolated from poultry litter, for a total of 255 isolates. All presumptive enterococcal strains were confirmed and classified; five isolates originally found in the samples could not be resuscitated on the standard media used in this study and were not included in the further experiments. Among the surface water samples, out of 23 possible Enterococcus species [24], nine species (including all other species) were detected and their percentages differed among locations and environmental compartments (Table 1). E. faecalis and E. faecium (characteristic of the digestive tract of human and warm-blooded animals) were the predominant species in surface water (27\% and $26 \%$, respectively), consistent with previous reports [2,9,30]. E. casseliflavus, E. gallinarum, E. hirae and E. durans were isolated from the poultry litter samples in this study, which is consistent with the literature, in that they are generally regarded as animal-derived strains, found in the gastrointestinal tract of poultry [31,32]. Our observation of their occurrence in surface and ground water samples may be indicative of contamination from the poultry farms of these environmental samples.

\subsection{Antimicrobial Resistance}

Antimicrobial resistance is a major global health concern, leading to development of monitoring programs such as the National Antimicrobial Resistance Monitoring Systems (NARMS) [33] in the USA and the European Antimicrobial Resistance Surveillance System (EARSS) [34] in Europe. Two hundred and fifty enterococcal isolates were tested for antimicrobial susceptibility; all 250 isolates were found to be susceptible to linezolid and tigecycline regardless of origin (litter, surface or ground water) and all isolates except two (both from broiler litter) were susceptible to gentamicin. All isolates except three (one from surface water site S6 and two from poultry litter) were resistant to at least one of the 16 clinical antibiotics tested and five isolates from broiler litter were resistant to nine antibiotics. Low resistance to gentamicin is consistent with previous studies [35-37]. Only one isolate (0.39\%) was resistant to chloramphenicol (surface water sample from location S6).

\subsubsection{Litter Samples}

Enterococci isolates from litter from both farms showed high resistance $(>50 \%$ resistant) to lincomycin $(80.3 \%)$, tetracycline $(65.3 \%)$, and penicillin $(61.1 \%)$ (Figure 1). In contrast, resistance to ciprofloxacin $(49.6 \%)$, streptomycin $(35.2 \%)$, erythromycin $(32.2 \%)$, tylosin $(31.4 \%)$, and Synercid ${ }^{\circledR}$ (26.0\%) was classified as medium (25-50\% resistance), whereas resistance to kanamycin $(8.5 \%)$, nitrofurantoin $(3.8 \%)$, daptomycin $(3.5 \%)$ and gentamicin $(0.8 \%)$ was low (<25\% resistant) (Figure 1$)$. 
Similar resistance values were observed for ciprofloxacin, nitrofurantoin and penicillin for litter from layers and broilers day 35 (both sampled from aged litter). High resistance to lincomycin and tetracycline by enterococci was observed for both the day 3 and day 35 broiler litter samples, whereas enterococci from layers had much lower resistance to these two antibiotics. This could be due to larger quantities of antimicrobial agents and growth promoters used in broiler compared to egg-laying husbandry. A previous study of antimicrobial resistance of two enterococcal species, E. faecium and E. faecalis, isolated from poultry litter likewise reported much lower resistance to erythromycin, ciprofloxacin and streptomycin for E. faecium from layers compared to broilers [38]. Our data also showed much lower resistance to all antibiotics (except daptomycin) for E. faecium isolated from layer compared to broiler litter. Resistance levels in E. faecium and E. faecalis from broilers were similar to results in a previous study conducted in Belgium [35].

Figure 1. Percent antibiotic resistance for enterococci. Enterococci isolated from poultry litter and environmental water samples were tested against a panel of 16 antimicrobials. Percent resistant enterococci from poultry litter (solid bar) and water (hatched bar) are shown for each antimicrobial; intermediate resistant isolates for each source are shown in the open bars. All isolates were susceptible to linezolid and tigecycline; only one isolate $(E$. faecalis from water) was resistant to chloramphenicol (data not shown).

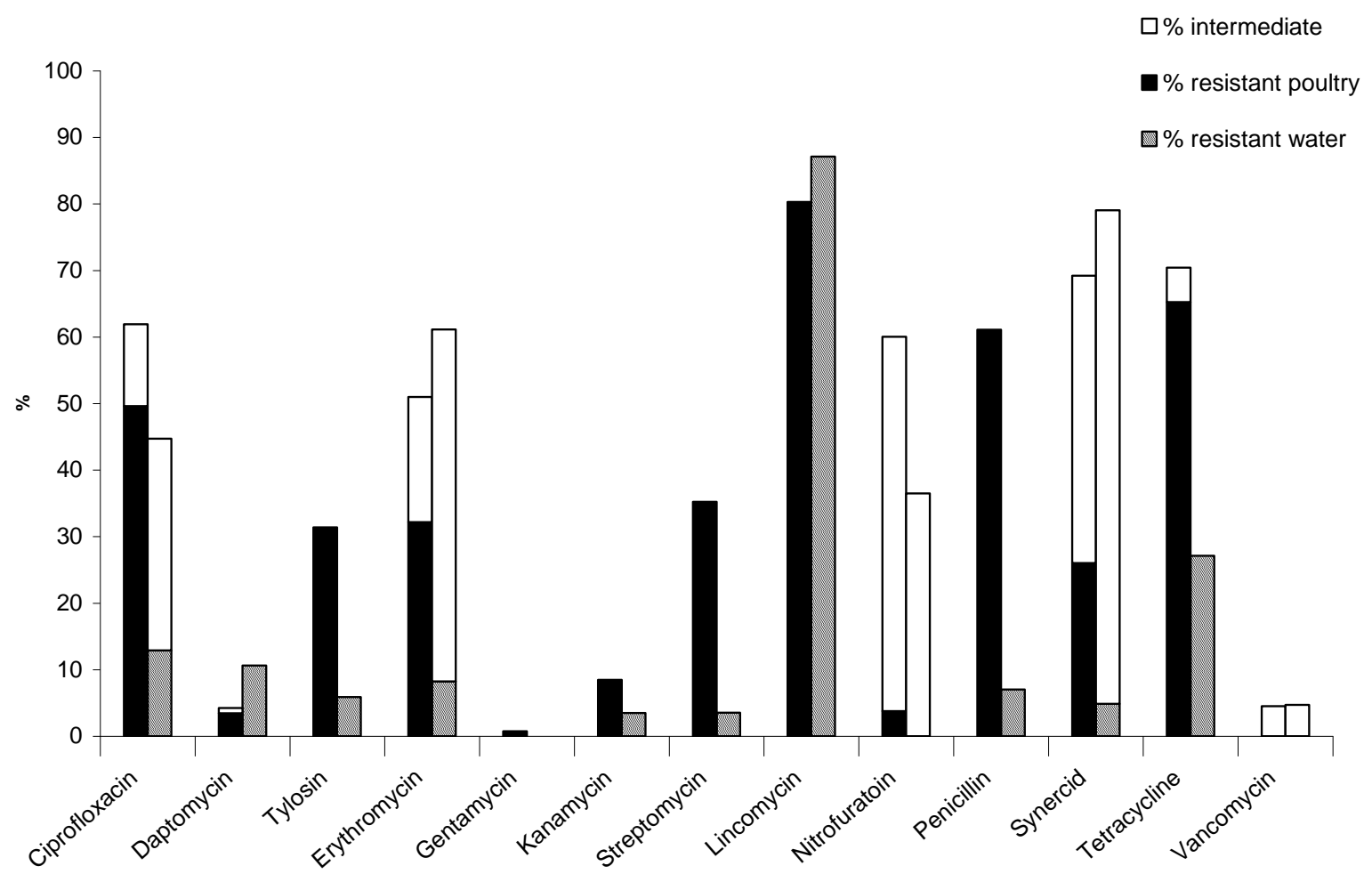

Our results as well as two other studies [35,38] confirmed high resistance of enterococci from poultry litter to lincosamides (lincomycin in this study). Those studies also reported high levels of resistance to macrolides whereas we reported medium levels of resistance to erythromycin and tylosin. Taken together, these results suggest similarities around the globe. Interestingly, high resistance to tetracycline (75.6\%), erythromycin (56.8\%) and ciprofloxacin $(41.9 \%)$ were reported in a previous study of Enterococcus isolated from poultry intestines immediately after slaughtering [39]. However, 
analysis of changes in prevalence and patterns of antimicrobial resistance among Enterococcus spp. isolated from growing broilers and their feces compared to a control group indicated that antimicrobials were not necessarily the cause of increased resistance to ampicillin, tetracycline, erythromycin and nitrofurantoin [40]. Rather, strains present in feed and farmhouse environments may colonize broiler intestines and cause shifts in the prevalence of resistance. Regardless of the underlying cause of resistance, it is critical that management practices be implemented such that resistant enterococci found in litter do not make their way into the environment and cause changes in the resistance patterns of environmental bacteria.

Only $4(14 \%)$ of the litter isolates from the layer farm were resistant to a single antibiotic, and $6(21 \%)$ were resistant to seven different antibiotics. All isolates from the broiler farm were MAR (resistant to at least two antibiotics). More recent studies are in agreement with our results, reporting higher levels of resistance to Synercid ${ }^{\circledR}$ and tylosin $[41,42]$.

\subsubsection{Water Samples}

Forty-one percent of enterococci surface water isolates $(n=36)$ were resistant to one antibiotic and 59\% were MAR. Resistance of enterococci from surface water samples to lincomycin was high (87.1\%); resistance to tetracycline $(27.1 \%)$ was medium, while low resistance was observed for ciprofloxacin $(12.9 \%)$, Synercid $^{\circledR}(15.7 \%)$ daptomycin (10.6\%), erythromycin (8.2\%), tylosin (5.9\%), streptomycin (3.5\%), penicillin (7.6\%), and kanamycin (3.5\%). In addition to these isolates with full resistance, there were a number of isolates with intermediate resistance to ciprofloxacin (31.8\%), erythromycin $(52.9 \%)$, Synercid ${ }^{\circledR}(74.2 \%)$, nitrofurantoin $(36.5 \%)$ and vancomycin $(1.2 \%)$. Previous studies reported little to no vancomycin resistance in poultry production environments [37,42-44]. Use of avoparcin is associated with emergence of vancomycin resistant Enterococcus (VRE), but since avoparcin has never been used in poultry production in Canada or the USA, our findings are in accordance with other studies $[36,43]$. The presence of intermediate resistant isolates could indicate a trend toward full resistance and in some studies intermediate is counted as resistant [30]. If that approach had been taken in this study, the percentage of resistant isolates would increase significantly as many isolates investigated in this study showed intermediate resistance (Figure 1). All ground water isolates were MAR, resistant to at least two antibiotics and as many as four antibiotics.

When resistance in the environmental isolates is examined by species (Table 2), all E. faecium and E. faecalis isolates ( $24.5 \%$ and $26.6 \%$ of total samples, respectively) were susceptible to daptomycin and vancomycin. Lincomycin and tetracycline resistance levels were noticeably higher in E. faecalis than E. faecium. E. faecium had higher levels of ciprofloxacin and penicillin resistance (Table 2). It should be noted that E. faecalis is intrinsically resistant to Synercid ${ }^{\circledR}$, thus those levels cannot be compared between the two species. E. hirae and E. durans from water samples and poultry samples were resistant to lincomycin, tetracycline, tylosin, erythromycin and nitrofurantoin (Table 2) which could be indicative of the same origin. Enterococci isolated from untreated waters for human consumption in Portugal have also shown resistance to ciprofloxacin, erythromycin and tetracyclines, implying that resistance to these antibiotics may be a widespread issue [9]. 
Table 2. Antimicrobial resistance profiles of enterococci from surface water and poultry litter samples from both broiler and layers barns.

\begin{tabular}{|c|c|c|c|c|c|c|c|c|}
\hline \multirow[b]{2}{*}{ Antimicrobial } & \multirow{2}{*}{$\begin{array}{l}\text { Break- } \\
\text { point } \\
(\mu \mathrm{g} / \mathrm{mL})\end{array}$} & \multirow[b]{2}{*}{ Source } & \multicolumn{6}{|c|}{ No. $(\%)$ of isolates resistant } \\
\hline & & & $\begin{array}{l}\text { E. faecalis } \\
(\mathrm{n}=57)\end{array}$ & $\begin{array}{l}\text { E. faecium } \\
(\mathbf{n}=\mathbf{8 8})\end{array}$ & $\begin{array}{l}\text { E. gallinarum } \\
(\mathbf{n}=\mathbf{3 0})\end{array}$ & $\begin{array}{l}\text { E. hirae } \\
(\mathrm{n}=32)\end{array}$ & $\begin{array}{l}\text { E. durans } \\
(\mathrm{n}=11)\end{array}$ & $\begin{array}{l}\text { All other } \\
\text { species }(n=32)\end{array}$ \\
\hline \multirow[t]{3}{*}{ Chloramphenicol } & $\geq 32$ & Water & $1(1.8)$ & 0 & 0 & 0 & 0 & 0 \\
\hline & & Layers & & 0 & & & & \\
\hline & & Broilers & 0 & 0 & 0 & 0 & 0 & 0 \\
\hline \multirow[t]{3}{*}{ Ciprofloxacin } & $\geq 4$ & Water & $1(1.8)$ & $11(12.5)$ & 0 & 0 & 0 & 1 \\
\hline & & Layers & & $22(25)$ & & & & \\
\hline & & Broilers & 0 & $25(28.4)$ & $2(6.7)$ & $1(3.1)$ & 0 & 0 \\
\hline \multirow[t]{3}{*}{ Daptomycin } & $\geq 8$ & Water & 0 & 0 & 0 & $1(3.1)$ & 0 & 9 \\
\hline & & Layers & & $2(2.3)$ & & & & \\
\hline & & Broilers & 0 & 0 & 0 & 0 & 0 & 0 \\
\hline \multirow[t]{3}{*}{ Tylosin } & $\geq 32$ & Water & $2(3.5)$ & 0 & 0 & $1(3.1)$ & $3(27.2)$ & 0 \\
\hline & & Layers & & $6(6.8)$ & & & & \\
\hline & & Broilers & $17(29.8)$ & $6(6.8)$ & $25(83.3)$ & $2(6.3)$ & $2(18.2)$ & 3 \\
\hline \multirow[t]{3}{*}{ Erythromycin } & $\geq 8$ & Water & $2(3.5)$ & $1(1.1)$ & 0 & $1(3.1)$ & $3(27.2)$ & 1 \\
\hline & & Layers & & $6(6.8)$ & & & & \\
\hline & & Broilers & $17(29.8)$ & $8(9.1)$ & $25(83.3)$ & $2(6.3)$ & $2(18.2)$ & 3 \\
\hline \multirow[t]{3}{*}{ Kanamycin } & $\geq 1,024$ & Water & $1(1.8)$ & $1(1.1)$ & 0 & $1(3.1)$ & 0 & 0 \\
\hline & & Layers & & $1(1.1)$ & & & & \\
\hline & & Broilers & $4(7.0)$ & $6(6.8)$ & $5(16.7)$ & $2(6.3)$ & 0 & 0 \\
\hline \multirow[t]{3}{*}{ Streptomycin } & $>1,000$ & Water & $1(1.8)$ & $1(1.1)$ & 0 & 0 & $3(27.2)$ & 0 \\
\hline & & Layers & & $8(9.1)$ & & & & \\
\hline & & Broilers & $8(14.0)$ & $22(25)$ & $20(66.7)$ & $1(3.1)$ & $2(18.2)$ & 1 \\
\hline \multirow[t]{3}{*}{ Lincomycin } & $>1,000$ & Water & $24(42.1)$ & $13(14.8)$ & $2(6.7)$ & $4(12.5)$ & $9(81.8)$ & 29 \\
\hline & & Layers & & $18(20.5)$ & & & & \\
\hline & & Broilers & $32(56.1)$ & 34 (38.6) & & $\begin{array}{l}28 \\
(87.5)\end{array}$ & $2(18.2)$ & 3 \\
\hline \multirow[t]{3}{*}{ Nitrofurantoin } & $\geq 128$ & Water & 0 & $2(2.3)$ & 0 & $1(3.1)$ & $4(36.4)$ & 0 \\
\hline & & Layers & & 0 & & & & \\
\hline & & Broilers & 0 & $4(4.5)$ & 0 & $4(12.5)$ & $1(0.9)$ & 0 \\
\hline \multirow[t]{3}{*}{ Penicillin } & $\geq 16$ & Water & 0 & $5(5.7)$ & 0 & $1(3.1)$ & 0 & 0 \\
\hline & & Layers & & $23(26.1)$ & & & & \\
\hline & & Broilers & 0 & $31(35.2)$ & 0 & $24(75)$ & 0 & 0 \\
\hline \multirow[t]{3}{*}{ Synercid $^{\circledR}$} & $\geq 4$ & Water & $24(42.1)$ & $1(1.1)$ & 0 & $1(3.1)$ & 0 & 1 \\
\hline & & Layers & & $2(2.3)$ & & & & \\
\hline & & Broilers & $32(56.1)$ & $19(21.6)$ & $3(10)$ & $1(3.1)$ & $2(18.2)$ & 1 \\
\hline \multirow[t]{3}{*}{ Tetracycline } & $\geq 16$ & Water & $13(22.8)$ & $7(8.0)$ & 0 & $1(3.1)$ & $5(45.5)$ & 1 \\
\hline & & Layers & & $13(14.8)$ & & & & \\
\hline & & Broilers & $22(38.6)$ & $31(35.2)$ & $27(90)$ & $\begin{array}{l}27 \\
(84.4)\end{array}$ & $2(18.2)$ & 2 \\
\hline \multirow[t]{3}{*}{ Gentamicin } & $\geq 500$ & Water & 0 & 0 & 0 & 0 & 0 & 0 \\
\hline & & Layers & & 0 & & & & \\
\hline & & Broilers & 0 & 0 & 0 & $2(6.3)$ & 0 & 0 \\
\hline
\end{tabular}




\subsubsection{Resistance Patterns}

A total of 54 resistance patterns for litter and environmental enterococci isolates were observed (Table 3). Only $17 \%$ of isolates were resistant to one of the 16 antibiotics tested. Resistance to a single antibiotic may not be a meaningful measure for study comparisons because the same isolates may be resistant to other antibiotics not tested.

Table 3. Antibiotic resistance patterns for Enterococcus spp. in litter and water.

\begin{tabular}{|c|c|c|c|c|}
\hline \multirow[b]{2}{*}{ No. antimicrobials } & \multirow[b]{2}{*}{ Resistance pattern $^{\text {a }}$} & \multirow[b]{2}{*}{ Species (No. isolates) } & \multicolumn{2}{|c|}{ Source } \\
\hline & & & Litter & Environment \\
\hline \multirow[t]{2}{*}{9} & Lin Tet Pen Tyl Cip Str Syn Kan Nit & E. faecium (1) & 1 & \\
\hline & Lin Tet Pen Tyl Ery Cip Str Syn Kan Ni & E. faecium (4) & 4 & \\
\hline \multirow[t]{2}{*}{8} & Lin Tet Pen Tyl Ery Str Cip Syn & E. faecium (1) & 1 & \\
\hline & Lin Tet Tyl Ery Str Kan Chl & E. faecalis (1) & & 1 \\
\hline \multirow[t]{9}{*}{7} & Lin Tet Pen Ery Str Syn Cip & E. faecium (1) & 1 & \\
\hline & Lin Tet Tyl Ery Str Syn Kan & E. faecalis (4) & 4 & \\
\hline & & E. gallinarum (3) & 3 & \\
\hline & Lin Tet Pen Cip Str Syn Nit & E. hirae (1) & 1 & \\
\hline & Lin Tet Tyl Ery Str Syn Nit & E. durans (1) & 1 & \\
\hline & Lin Pen Tet Tyl Ery Cip Str & E. faecium (3) & 3 & \\
\hline & Lin Pen Tet Tyl Ery Str Syn & E. faecium (1) & 1 & \\
\hline & Lin Pet Tet Tyl Ery Str Kan & E. faecium (1) & 1 & \\
\hline & Lin Pen Tyl Cip Ery Str Syn & E. faecium (1) & 1 & \\
\hline \multirow[t]{4}{*}{6} & Lin Tet Pen Cip Syn Lin & E. faecium (9) & 9 & \\
\hline & Lin Tet Tyl Str Syn Ery & E. faecalis (1) & 1 & \\
\hline & Lin Tet Tyl Ery Str Kan & E. gallinarum (2) & 2 & \\
\hline & & E. durans (1) & 1 & \\
\hline \multirow[t]{6}{*}{5} & Lin Tet Pen Cip Str & E. faecium (4) & 4 & \\
\hline & Lin Tet Tyl Ery Syn & E. faecalis (13) & 12 & 1 \\
\hline & Lin Tet Tyl Ery Str & E. gallinarum (15) & 15 & \\
\hline & & E. durans (2) & & 2 \\
\hline & Lin Tet Pen Gen Kan & E. hirae (2) & 2 & \\
\hline & Lin Tet Pen Cip Dap & E. faecium (2) & 2 & \\
\hline \multirow[t]{11}{*}{4} & Lin Tet Pen Str & E. faecium (2) & 2 & \\
\hline & Lin Tet Pen Syn & E. faecium (2) & 2 & \\
\hline & Lin Tet Pen Cip & E. faecium (3) & 3 & \\
\hline & Lin Tet Ery Tyl & E. gallinarum (5) & 5 & \\
\hline & & E. hirae (2) & 2 & \\
\hline & & E. durans (1) & & 1 \\
\hline & & $E$. species $(1)$ & 1 & \\
\hline & Lin Tet Str Tet & E. faecium (1) & & 1 \\
\hline & Lin Tet Ery Kan & E. faecium (1) & & 1 \\
\hline & Lin Tet Pen Nit & E. hirae (3) & 3 & \\
\hline & Lin Pen Str Cip & E. faecium (1) & 1 & \\
\hline \multirow[t]{3}{*}{3} & Pen Cip Nit & E. faecium (1) & 1 & \\
\hline & Tet Pen Cip & E. faecium (4) & 3 & 1 \\
\hline & Lin Tet Ery & E. faecium (1) & 1 & \\
\hline
\end{tabular}


Table 3. Cont.

\begin{tabular}{|c|c|c|c|c|}
\hline \multirow[b]{2}{*}{ No. antimicrobials } & \multirow[b]{2}{*}{ Resistance pattern $^{\text {a }}$} & \multirow[b]{2}{*}{ Species (No. isolates) } & \multicolumn{2}{|c|}{ Source } \\
\hline & & & Litter & Environment \\
\hline & & E. raffinosus (1) & & 1 \\
\hline & Lin Tet Syn & E. faecalis (17) & 5 & 12 \\
\hline & Lin Tet Str & E. durans (1) & & 1 \\
\hline & Lin Str Syn & E. faecalis (3) & 3 & \\
\hline & Lin Tet Cip & E. faecium (1) & & 1 \\
\hline & & E. gallinarum (1) & 1 & \\
\hline & Lin Tet Pen & E. faecium (2) & 1 & 1 \\
\hline & & E. hirae (18) & 18 & \\
\hline & Lin Tyl Ery & E. species (1) & 1 & \\
\hline & Lin Syn Cip & E. faecalis (1) & & 1 \\
\hline & Lin Pen Cip & E. faecium (6) & 6 & \\
\hline & Tet Cip Str & E. faecium (1) & 1 & \\
\hline 2 & Lin Tet & E. faecium (4) & 4 & \\
\hline & & E. gallinarum (1) & 1 & \\
\hline & & E. hirae (1) & 1 & \\
\hline & & E. durans (1) & & 1 \\
\hline & Lin Nit & E. faecium (1) & 1 & \\
\hline & Lin Syn & E. faecalis (16) & 7 & 9 \\
\hline & & E. hirae (1) & & 1 \\
\hline & & $E$. species (1) & & 1 \\
\hline & Pen Tet & E. faecium (2) & & 2 \\
\hline & & E. gallinarum (1) & 1 & \\
\hline & Pen Cip & E. faecium (6) & 3 & 3 \\
\hline & & E. casseliflavus (1) & & 1 \\
\hline & Lin Dap & E. hirae (1) & & 1 \\
\hline & & E. mundtii (11) & & 11 \\
\hline 1 & Pen & E. faecium (2) & 2 & \\
\hline & Lin & E. faecium (5) & & 5 \\
\hline & & E. faecalis (1) & & 1 \\
\hline & & E. gallinarum (2) & & 2 \\
\hline & & E. hirae (2) & 1 & 1 \\
\hline & & E. durans (4) & & 4 \\
\hline & & E. casseliflavus (7) & & 7 \\
\hline & & $E$. species (8) & & 8 \\
\hline & & E. mundtii (1) & & 1 \\
\hline & Cip & E. faecium (10) & 3 & 7 \\
\hline & Tet & E. faecium (1) & & 1 \\
\hline Total & & & 157 & 93 \\
\hline
\end{tabular}

${ }^{\mathrm{a}}$ Cip = Ciprofloxacin, $\mathrm{Chl}=$ Chloramphenicol, Dap = Daptomycin, Ery = Erythromycin, Gen = Gentamicin,

Kan $=$ Kanamycin, Lin $=$ Lincomycin, Nit $=$ Nitrofurantoin, Pen $=$ Penicillin, Str $=$ Streptomycin, Syn $=$ Synercid $^{\circledR}$, Tet $=$ Tetracycline, Tyl $=$ Tylosin.

For example, a previous study of bacitracin resistance by enterococci isolates from chicken ceca or feces showed that all samples were resistant to at least two different classes of antibiotics, and bacitracin resistance was present in all patterns [43]. Bacitracin was excluded from USDA 
NARMS plates because virtually all enterococci, regardless of species, are resistant to that antimicrobial. Another study in France observed that three of 16 antibiotics tested (largely different than those tested in this study) accounted for $96 \%$ of antimicrobial resistance present in $E$. coli isolated from rivers [19]. This confirms that the choice of antibiotics determines the prevalence of AR, making comparison among studies difficult.

Several E. faecium and E. faecalis isolates from litter and the environment had the same resistance pattern (ciprofloxacin, ciprofloxacin/penicillin, lincomycin/tetracycline/Synercid ${ }^{\circledR}$, lincomycin/ tetra-cycline/tylosin/erythromycin/Synercid ${ }^{\circledR}$; Table 3). The resistance patterns of the isolates reflect the antibiotic use in poultry production in the area; for example, lincomycin, tetracycline, penicillin, and tylosin use was reported previously [43]. Resistance to erythromycin and tetracycline was also reported in Denmark for E. faecium and E. faecalis in broilers [45]. Unlike many other coliforms (such as E. coli), intestinal enterococci species antimicrobial resistance properties differ notably between humans and different species of animals, resulting in specific patterns which could be used to differentiate of contamination sources.

\subsection{MAR Indices}

To assess the relative prevalence of resistant enterococci in the environment, MAR indices were calculated and compared with those previously published (Table 4). For all surface water sites, MAR indices were between 0.06 and 0.19 ; for litter samples, the average MAR index was $0.27 \pm 0.07$. In a study of fecal discharge to the Seine River, Enterococcus MAR indices were found to be 0.24 for a point source (i.e., hospital wastewaters), indicating high antibiotic use, compared to values of 0.078 for an agricultural non-point source and 0.168 for the river itself [19]. Panda et al. [11] monitored MAR pathogens in the Bay of Bengal, India and reported a high MAR index of 0.083 although it is not clear for which bacteria it was calculated, which may be important based on data reported for E. coli $[19,28]$. MAR indices calculated in this study for litter $(0.27)$ were approximately double the water values. Although the introduction of resistant enterococci into the environment from farm run-off would be diluted during passage to proximate surface waters, the relatively high MAR indices at some surface water sites likely indicates inputs from poultry operations as no other wastewater sources in the area were observed. Because there are no criteria for MAR index for enterococci, it is difficult to assess human health risks due to presence of resistant enterococci in the water. Based on comparison of MAR indices from E. coli isolates from a variety of sources, Krumperman [28] suggested a MAR index of 0.200 to differentiate between low and high-risk contamination, although he acknowledged that this value was arbitrary. Although our results comparing litter and surface water MAR indices suggest poultry contamination of the environment, the risk posed by this contamination may be low given all surface water MAR values were $<0.2$. Further detailed studies of MAR indices for enterococci are needed for risk assessment. 
Table 4. AR, MAR and MAR indices for enterococci isolates.

\begin{tabular}{lrrrr}
\hline & AR & MAR & MAR index \\
\cline { 2 - 5 } Surface water & $\geq 1(\%)$ & $\geq 2(\%)$ & $\geq 5(\%)$ & \\
S1 & 100 & 63 & 13 & 0.141 \\
S2 & 100 & 40 & 0 & 0.071 \\
S3 & 100 & 75 & 0 & 0.133 \\
S4 & 100 & 80 & 10 & 0.138 \\
S6 & 90 & 40 & 10 & 0.131 \\
S7 & 100 & 29 & 29 & 0.125 \\
S8 & 0 & 100 & 0 & 0.188 \\
S9 & 100 & 0 & 0 & 0.063 \\
S11 & 100 & 71 & 0 & 0.107 \\
S12 & 100 & 71 & 0 & 0.107 \\
Groundwater & & & & \\
& 0 & 5 & 0 & 0.188 \\
Poultry farms & & & & \\
Layers & 97 & 83 & 28 & 0.218 \\
Broilers (day3) & 100 & 98 & 44 & 0.248 \\
Broilers (day 35) & 100 & 100 & 83 & 0.358 \\
\hline
\end{tabular}

$\mathrm{AR}=$ resistance to one antibiotic; $\mathrm{MAR}=$ resistance to at least two antibiotics.

\section{Conclusions}

This study confirmed the presence of resistant enterococci species in the environment, specifically surface and ground water. The majority of isolates were MAR and some water isolates exhibited the same resistance pattern as isolates from poultry litter. Although these antibiotics are not used in poultry production, resistance to lincomycin, tetracycline, penicillin, and ciprofloxacin in surface water and litter was observed. These resistances may have resulted from cross-resistance to other antibiotics in the same class which are used in poultry production. Cross-resistance to antibiotics in enterococci may limit antibiotic efficacy in human medicine. MAR indices calculated for surface water samples suggest increased presence of antibiotic resistant enterococci in the surface water tested. Results from this study could be beneficial for improvement of best management practices in the area.

\section{Acknowledgments}

We would like to thank Health Canada for funding this research. Many thanks are due to the anonymous reviewers for very constructive suggestions.

\section{Conflict of Interest}

The authors declare no conflict of interest. 


\section{References}

1. Araujo, C.; Torres, C.; Silva, N.; Carneiro, C.; Goncalves, A.; Radhouani, H.; Correia, S.; da Costa, P.M.; Paccheco, R.; Zarazaga, M.; Ruiz-Larrea, F.; Poeta, P.; Igrejas, G. Vancomycin-resistant enterococci from Portuguese wastewater treatment plants. J. Basic Microbiol. 2010, 50, 605-609.

2. Lanthier, M.; Scott, A.; Zhang, Y.; Cloutier, M.; Durie, D.; Henderson, V.C.; Wilkes, G.; Lapen, D.R.; Topp, E. Distribution of selected virulence genes and antibiotic resistance in Enterococcus species isolated from the South Nation River drainage basin, Ontario, Canada. J. Appl. Microbiol. 2011, 110, 407-421.

3. Novo, A.; Manaia, C.M. Factors influencing antibiotic resistance burden in municipal wastewater treatment plants. Appl. Microbiol. Biotechnol. 2010, 87, 1157-1166.

4. Kotzamanidis, C.; Zdragas, A.; Kourelis, A.; Moraitou, E.; Papa, A.; Yiantzi, V.; Pantelidou, C.; Yiangou, M. Characterization of vanA-type Enterococcus faecium isolates from urban and hospital wastewater and pigs. J. Appl. Microbiol. 2009, 107, 997-1005.

5. Jackson, C.R.; Furtula, V.; Farrell, E.G.; Barrett, J.B.; Hiott, L.M.; Chambers, P. A comparison of BOX-PCR and pulsed-field gel electrophoresis to determine genetic relatedness of enterococci from different environments. Microb. Ecol. 2012, 64, 378-387.

6. Facklam, R.R.; Sahm, D.F.; Teixeiram, L.M. Enterococcus. In Manual of Clinical Microbiology, 7th ed.; Murray, P.R., Baron, E.J., Pfaller, M.A., Tenover, F.C., Yolken, R.H., Eds.; ASM Press: Washington, DC, USA, 1999; pp. 297-305.

7. Malani, P.N.; Kauffman, C.A.; Zervos, M.J. Enterococcal disease, epidemiology, and treatment. In The Enterococci: Pathogenesis, Molecular Biology, and Antibiotic Resistance; Gilmore, M.S., Clewell, D.B., Courvalin, P., Dunny, G.M., Murray, B.E., Rice, L.B., Eds.; ASM Press: Washington, DC, USA, 2002; pp. 385-408.

8. Cetinkaya, Y.; Falk, P.; Mayhall, C.G. Vancomycin-resistant enterococci. Clin. Microbiol. Rev. 2000, 13, 686-707.

9. Macedo, A.S.; Freitas, A.R.; Abreu, C.; Machado, E.; Peixe, L.; Sousa, J.C.; Novais, C. Characterization of antibiotic resistant enterococci isolated from untreated waters for human consumption in Portugal. Int. J. Food Microbiol. 2011, 145, 315-319.

10. McGowan, L.L.; Jackson, C.R.; Barrett, J.B.; Hiott, L.M.; Fedorka-Cray, P.J. Prevalence and antimicrobial resistance of enterococci isolated from retail fruits, vegetables, and meats. J. Food Prot. 2006, 69, 2976-2982.

11. Panda, S.K.; Patra, A.K.; Kar, R.N. Monitoring of multiple drug-resistant pathogens in a selected stretch of Bay of Bengal, India. Environ. Monit. Assess. 2011, 5, 83-98.

12. Murray, B.E. Diversity among multidrug-resistant enterococci. Emerg. Infect. Dis. 1998,4, $37-47$.

13. Brooks, J.P.; Adeli, A.; Read, J.J.; McLaughlin, M.R. Rainfall simulation in greenhouse microcosms to assess bacterial-associated runoff from land-applied poultry litter. J. Environ. Qual. 2009, 38, 218-229. 
14. Diarrassouba, F.; Diarra, M.S.; Bach, S.; Delaquis, P.; Pritchard, J.; Topp, E.; Skura, B.J. Antibiotic resistance and virulence genes in commensal Escherichia coli and Salmonella isolates from commercial broiler chicken farms. J. Food Prot. 2007, 70, 1316-1327.

15. Furtula, V.; Farrell, E.G.; Diarrassouba, F.; Rempel, H.; Pritchard, J.; Diarra, M.S. Veterinary pharmaceuticals and antibiotic resistance of Escherichia coli isolates in poultry litter from commercial farms and controlled feeding trials. Poult. Sci. 2010, 89, 180-188.

16. Kelley, T.R.; Pancorbo, O.C.; Merka, W.C.; Thompson, S.A.; Cabrera, M.L.; Barnhart, H.M. Bacterial pathogens and indicators in poultry litter during re-utilization. J. Appl. Poultry Res. 1995, 4, 366-373.

17. Graham, J.P.; Evans, S.L.; Price, L.B.; Silbergeld, E.K. Fate of antimicrobial-resistant enterococci and staphylococci and resistance determinants in stored poultry litter. Environ. Res. 2009, 109, 682-689.

18. Jenkins, M.B.; Truman, C.C.; Siragusa, G.; Line, E.; Bailey, J.S.; Frye, J.; Endale, D.M.; Franklin, D.H.; Schomberg, H.H.; Fisher, D.S.; Sharpe, R.R. Rainfall and tillage effects on transport of fecal bacteria and sex hormones 17beta-estradiol and testosterone from broiler litter applications to a Georgia Piedmont Ultisol. Sci. Total Environ. 2008, 403, 154-163.

19. Servais, P.; Passerat, J. Antimicrobial resistance of fecal bacteria in waters of the Seine river watershed (France). Sci. Total Environ. 2009, 408, 365-372.

20. Lata, P.; Ram, S.; Agrawal, M.; Shanker, R. Enterococci in river Ganga surface waters: Propensity of species distribution, dissemination of antimicrobial-resistance and virulence-markers among species along landscape. BMC Microbiol. 2009, 9, 140-149.

21. Moore, D.F.; Guzman, J.A.; McGee, C. Species distribution and antimicrobial resistance of enterococci isolated from surface and ocean water. J. Appl. Microbiol. 2008, 105, 1017-1025.

22. Furtula, V.; Jackson, C.R.; Osman, R.; Chambers, P.A. Use of Enterococcus, BST and sterols for poultry pollution source tracking in surface and groundwater. In Environmental Health-Emerging Issues and Practice; Oosthuizen, J., Ed.; InTech Open Access: Rijeka, Croatia, 2012; pp. 57-78.

23. Improved Enumeration Methods for the Recreational Water Quality Indicators: Enterococci and Escherichia coli; USEPA: Washington, DC, USA, 2000; pp. 1-49.

24. Jackson, C.R.; Fedorka-Cray, P.J.; Barrett, J.B. Use of a genus- and species-specific multiplex PCR for identification of enterococci. J. Clin. Microbiol. 2004, 42, 3558-3565.

25. Bacterial Epidemiology and Antimicrobial Resistance: NARMS - National Antimicrobial Resistance Monitoring System Animal Isolates. Available online: http://www.ars.usda.gov/ Main/docs.htm? docid=6750\&page=3 (accessed on 7 March 2013).

26. Methods for Dilution Antimicrobial Susceptibility Tests for Bacteria that Grow Aerobically, 7th ed.; Clinical and Laboratory Standards Institute (CLSI): Villanova, PA, USA, 2006.

27. Performance Standards for Antimicrobial Susceptibility Testing, Seventh Informational Supplement; Clinical and Laboratory Standards Institute (CLSI): Wayne, PA, USA, 2007.

28. Krumperman, P.H. Multiple antibiotic resistance indexing of Escherichia coli to identify high-risk sources of fecal contamination of foods. Appl. Environ. Microbiol. 1983, 46, 165-170.

29. The European Parliament and the Council of the European Union Directive. Available online: http://eur-lex.europa.eu/LexUriServ/LexUriServ.do?uri=OJ:L:2006:064:0037:0051:EN:PDF (accessed on 29 October 2012). 
30. Luczkiewicz, A.; Jankowska, K.; Kurlenda, J.; Olanczuk-Neyman, K. Identification and antimicrobial resistance of Enterococcus spp.isolated from surface water. Water Sci. Technol. 2010, 62, 466-473.

31. Thal, L.A.; Chow, J.W.; Mahayni, R.; Bonilla, H.; Perri, M.B.; Donabedian, S.A.; Silverman, J.; Taber, S.; Zervos, M.J. Characterization of antimicrobial resistance in enterococci of animal origin. Antimicrob. Agents Chemother. 1995, 39, 2112-2115.

32. Simjee, S.; White, D.G.; McDermott, P.F.; Wagner, D.D.; Zervos, M.J.; Donabedian, S.M.; English, L.L.; Hayes, J.R.; Walker, R.D. Characterization of Tn1546 in vancomycin-resistant Enterococcus faecium isolated from canine urinary tract infections: Evidence of gene exchange between human and animal enterococci. J. Clin. Microbiol. 2002, 40, 4659-4665.

33. Fedorka-Cray, P.J.; Englen, M.D.; Gray, J.T.; Hudson, C.; Headrick, M.L. Programs for monitoring antimicrobial resistance. Animal Biotech. 2002, 13, 43-55.

34. Fluit, A.C.; van der Bruggen, J.T.; Aarestrup, F.M.; Verhoef, J.; Jansen, W.T. Priorities for antibiotic resistance surveillance in Europe. Clin. Microbiol. Infect. 2006, 12, 410-417.

35. Butaye, P.; Devriese, L.A.; Haesebrouck, F. Differences in antibiotic resistance patterns of Enterococcus faecalis and Enterococcus faecium strains isolated from farm and pet animals. Antimicrob. Agents Chemother. 2001, 45, 1374-1378.

36. Petsaris, O.; Miszczak, F.; Gicquel-Bruneau, M.; Perrin-Guyomard, A.; Humbert, F.; Sanders, P.; Leclercq, R. Combined antimicrobial resistance in Enterococcus faecium isolated from chickens. Appl. Environ. Microbiol. 2005, 71, 2796-2799.

37. Butaye, P.; Baele, M.; Devriese, L.A.; Haesebrouck, F. Comparison of susceptibility to antimicrobials of the enterococcal species isolated from pigeons (Columba livia). Microb. Drug Resist. 2002, 8, 215-218.

38. Yoshimura, H.; Ishimaru, M.; Endoh, Y.S.; Kojima, A. Antimicrobial susceptibilities of enterococci isolated from faeces of broiler and layer chickens. Lett. Appl. Microbiol. 2000, 31, 427-432.

39. Ruzauskas, M.; Siugzdiniene, R.; Spakauskas, V.; Povilonis, J.; Seputiene, V.; Suziedeliene, E.; Daugelavicius, R.; Pavilonis, A. Susceptibility of bacteria of the Enterococcus genus isolated from Lithuanian poultry farms. Vet. Med. 2009, 54, 583-588.

40. Da Costa, P.M.; Belo, A.; Goncalves, J.; Bernardo, F. Field trial evaluating changes in prevalence and patterns of antimicrobial resistance among Escherichia coli and Enterococcus spp.isolated from growing broilers medicated with enrofloxacin, apramycin and amoxicillin. Vet. Microbiol. 2009, 139, 284-292.

41. Aslam, M.; Diarra, M.S.; Service, C.; Rempel, H. Characterization of antimicrobial resistance in Enterococcus spp. recovered from a commercial beef processing plant. Foodborne. Pathog. Dis. 2010, 7, 235-241.

42. Jacob, M.E.; Fox, J.T.; Narayanan, S.K.; Drouillard, J.S.; Renter, D.G.; Nagaraja, T.G. Effects of feeding wet corn distillers grains with solubles with or without monensin and tylosin on the prevalence and antimicrobial susceptibilities of fecal foodborne pathogenic and commensal bacteria in feedlot cattle. J. Anim. Sci. 2008, 86, 1182-1190. 
43. Diarra, M.S.; Rempel, H.; Champagne, J.; Masson, L.; Pritchard, J.; Topp, E. Distribution of antimicrobial resistance and virulence genes in Enterococcus spp. and characterization of isolates from broiler chickens. Appl. Environ. Microbiol. 2010, 76, 8033-8043.

44. Hayes, J.R.; English, L.L.; Carr, L.E.; Wagner, D.D.; Joseph, S.W. Multiple-antibiotic resistance of Enterococcus spp. isolated from commercial poultry production environments. Appl. Environ. Microbiol. 2004, 70, 6005-6011.

45. Aarestrup, F.M.; Agerso, Y.; Gerner-Smidt, P.; Madsen, M.; Jensen, L.B. Comparison of antimicrobial resistance phenotypes and resistance genes in Enterococcus faecalis and Enterococcus faecium from humans in the community, broilers, and pigs in Denmark. Diagn. Microbiol. Infect. Dis. 2000, 37, 127-137.

(C) 2013 by the authors; licensee MDPI, Basel, Switzerland. This article is an open access article distributed under the terms and conditions of the Creative Commons Attribution license (http://creativecommons.org/licenses/by/3.0/). 